\title{
ADVERB OF TIME IN ARABIC SIMPLE SENTENCE
}

\section{Muhammad Ivan Fauzi, Deli Nirmala, Agus Subiyanto}

Universitas Diponegoro (UNDIP), Semarang, Indonesia E-mail: ivanfauzi@students.undip.ac.id

Received: 29 October 2020

Accepted: 05 December 2020

\begin{abstract}
This research aims to describe the pattern of Arabic simple sentences attached by adverb of time and the distribution of the adverb of time in Arabic simple sentences. The research data are in the form of a simple sentence, which contains adverb of time from a paper in the book AlArabiyah Baina Yadaik Volume $4 a$ by Al-Fauzan, et al. (2014). The data collection was carried out using the observation method. The analysis of adverb of time in Arabic simple sentence was done by a tree diagram with the guidelines proposed by Chomsky (2002). The results showed that the adverb of time is inherent in verbs and was only found in the original verb and not a derivational verb. In addition, the sentence patterns of Arabic simple sentence attached by adverb of time consist of PS, SP, SPO, and PSO. The researchers also found the distribution of adverbs of time inside the predicate, behind the object, in front of the predicate, and behind the subject.
\end{abstract}

Keywords: adverb of the time, simple sentence, Arabic, tree diagram.

\section{Introduction}

As a means of communication, language is composed of words, phrases, and sentences. Every sentence that is spoken has an intonation and forming elements such as subject, predicate, object, complement, and adverb. But in general, sentences uttered by humans in everyday communication are not always complete, namely sentences that are composed of the constituent elements. Sometimes a sentence consists of only a subject, such as a word "I" which is the answer to the question "Who made this cake?". There are also sentences that are just adverbs, such as the sentence "to school" in response to the question "Where did Reno go?". In everyday speech, sentences are pronounced using intonation, but in written language, the sentence can only be given a punctuation mark to determine the speaker's intention. The sentences "I" and "to school" are grammatically acceptable sentences, because if the sentence is translated, it becomes "I made the bread" and "Reno went to school". The two sentences consist of a subject, predicate, and adverb, which are the building blocks of the sentence. Therefore, the two sentences have been translated into a simple sentence.

Simple sentences in Arabic have a variety of patterns and arrangements. Just like in Indonesian, a simple sentence in Arabic consists of one clause, but the difference is that a simple sentence in Arabic sometimes ends with a comma instead of a period. In a single Arabic sentence, the adverb of time is always present and must always be included. Apart from adverbs of time, Arabic also includes gender in every sentence. This is because the adverb of time in Arabic always accompanies the predicate. As an example of the sentence Akaltu arruzza 'I have eaten rice' and Akulu ar-ruzza 'I am eating rice'. The words 'akaltu' and 'akulu' are predicates which are always followed by an adverb of time. 
The adverb of time attached to the predicate can show the past as well as the present. The indicators of the past and present can be seen through the types of verbs and letters that accompany the verbs. In addition to the adverb of time which is always attached to the predicate, there is an independent time statement called zharaf zaman (adverb of time). The presence of zharf zama in a sentence does not always depend on the predicate. Without the predicate, zharaf zaman can already form sentences.

\section{Literature Review}

Research on word construction was carried out by Febriani, et al (2015), entitled "Morphological Process or Word Construction in Arabic". Through this study, researchers analyzed word-formation or morphological processes in Arabic through al-ziyādah (additions, additions, or extras). The results showed there were four types of al-ziyādah in the formation of Arabic verbs, namely-sawābiq, al-hasyw, al-lawāhiq, and al-muzdawijah. Word formation through al-ziyādah in Arabic is an addition of letters used to form the word which is the result of the formation of Arabic. Further research was done by Liusti (2016) entitled "Sentence Analysis Based on Basic Sentence Patterns and Predicate Calculus". this research analyzed sentences using the basic Indonesian sentence pattern approach and predicate calculus. Both approaches place of the predicate as a determining component for the presence of other components in the sentence structure. The research data are in the form of Indonesian declarative sentences. it was found that that the analysis of basic sentence patterns could only identify the internal elements of sentence patterns, while predicate calculus could simultaneously identify the internal elements of simple sentences and compound sentences.

Another research was written by Nur (2018) entitled "Statement of Kala and Aspects in Arabic: Semantic Analysis of Verbs". The research data are in the form of Arabic spoken sentences. The researcher used a structural linguistic approach in analyzing the data and it was found that perfect verb conjunctions ( $m \bar{a} d h i)$ to imperfect verbs (mudhāri ') can express the semantic concepts of times and aspects. Other elements that express the kala and aspects are the auxiliary verb kana particle qad, sawfa, lan, and the prefix sa-. The aid verb kana expresses the past time when interacting with the imperfect verb, but when interacting with the perfect verb it states the perfective aspect. Qad particles represent the perfective aspect when interacting with the perfect verb, whereas the particles sawfa, lan. Research on sentence construction was also written by Al-Shammiry (2016) with the title "Adverbs in Saudi Northern Region Dialect of Arabic", which revealed morpho-syntactic patterns and distribution of adverbs in sentences. The research data are in the form of everyday spoken sentences in one of the dialects of Saudi Arabia in the Northern Region. Based on data analysis, the researcher found that there were three types of adverbs used. Those adverbs were preverbal adverbs, post-verbal adverbs, and sentential adverbs.

Based on previous studies above, the research related to adverbs in sentence structure has been carried out. However, there is no research that focuses on the adverb of time in Arabic simple sentences using a tree diagram specifically. So this research needs to be done.

A simple sentence is a sentence that occurs from one free clause (Suharto and Fauzi, 2017). Meanwhile, according to Alwi, (in Liusti, 2016) a simple sentence is not always in a short form consisting only of a subject and predicate, but can also belong to the presence of arbitrary elements, such as objects, complements, or adverbs. From the experts' information, it can be concluded that a simple sentence is a sentence consisting of one clause and can stand alone. As an example of "Akaltu ar-ruzza" (I have eaten rice). This sentence consists of the subject "tu" (me), the predicate + adv of time "intellect + tu" (have eaten), and the object "ar- 
ruzza" (rice). Accordingly, Alwi (in Liusti, 2016) there are four main syntactic categories namely nouns, verbs, adjectives, and adverbs. According to Ramlan (2005: 85) clause elements that do not occupy the functions $\mathrm{S}, \mathrm{P}, \mathrm{O}$, and $\mathrm{C}$ can be estimated to occupy the ADV function. An adverb is part of the clause that is outside the core (Kridalaksana, 2002: 55). Moreover, adverbs are used to explain sentences or other parts that do not explain nature (Susandhika et.al, 2016). Arabic also has free ADV elements. One of the elements included in the adverb is the 'adverb of time'.

Adverb of time is a part of a clause that states when an event occurs or explains when a predicate occurs, which is concerned with when, how long, the duration, the frequency, since, and until when. Adverbs of time can be in the form of words, phrases, or sentences (Chomsky, 2002: 72, Kridalaksana, 2002: 121). According to Dahda (1981) In Arabic, the adverb of time can be a marker attached to a predicate and can also be a word that can stand alone. Verbs that have an adverb of time in Arabic are called fi'il madhi (perfect verb) and fi'il mudhari

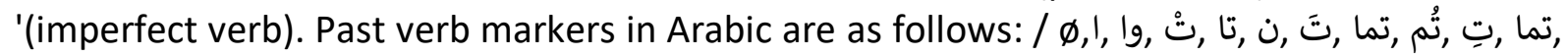
تن this marker is also useful as an indication of gender and the number of actors. Meanwhile, the present and future time markers in Arabic verbs are in front of the verb which consists of / , $ت, \dot{U}$, and 1/. Apart from showing the adverb of time, the marker also indicates gender (Dahda, 1981). Adverbs of time that can stand alone are called zharf zaman, consisting of qabla (before), ba'da (after), al-yaum (today), al-lailah (tonight), ghudwah (in the morning), bukrah (morning time), sakharan (sahur time), ghadan (tomorrow), shabākhan (at dawn), masā'an (in the evening), zamanan (forever), amadan (forever), khinan (when) (Schulz, 2012: 73).

According to Chomsky (2002: 146), one of the best ways to create a visual representation of syntactic structures is through tree diagrams, with the following symbols:

$\begin{array}{ll}\text { K } & \text { : Sentence } \\ \text { FN } & : \text { Noun Phrase } \\ \text { FV } & \text { : Verb Phrases } \\ \text { FP } & \text { : Prepositional Phrases } \\ \text { Par } & : \text { Particles } \\ \text { Art } & : \text { Articles } \\ \text { Gen } & : \text { Gender } \\ \text { ADV } & \text { : Adverb }\end{array}$

A tree diagram has branches down rather than upward that serve as a diagram that represents all of the grammatical information in the analysis. In addition, the tree diagram shows very explicitly that there are different levels of analysis.

\section{Research Method}

This research is qualitative research. The data collection method used is observation. The observation method is used to observe the simple sentence contained in the data source (Sudaryanto, 2015). The next technique is the note-taking technique. This technique is carried out by reads and notes the simple sentence attached by the adverb of time. The data is taken from papers contained in the book Al-Arabiyyah Baina Yadaik Volume 4a by Al-Fauzan, et al (2014). This object was chosen because it uses official Arabic and there are many simple sentences used as a learning media for beginners. Meanwhile, the data analysis method used is agih. The Agih method is a method in which the determinants are part of the language itself, 
such as words, syntactic functions, clauses, and so on (Sudaryanto, 2015). Agih method is used to determine the adverb of time. The technique used by researchers is direct distribution, namely the method used at the beginning of the analysis by dividing the lingual unit of data into parts or elements which are considered as a part of a lingual unit. The data analysis of adverb of time in Arabic sentences is by tree diagrams proposed by Chomsky (2002).

\section{Results and Discussion}

\section{The pattern of Arabic simple sentence attached by adverb of time}

In the book Al-'Arabiyah Baina Yadaik Volume 4a, there are 20 simple sentences that have an adverb of the time either attached to the predicate or independently. The following are the analysis of sentences containing adverbs of time based on their location in the Arabic simple sentence.

\section{Intasyārat at tadxīnu}

(spread) (had) (a) (cigarette)

"Cigarettes have spread."

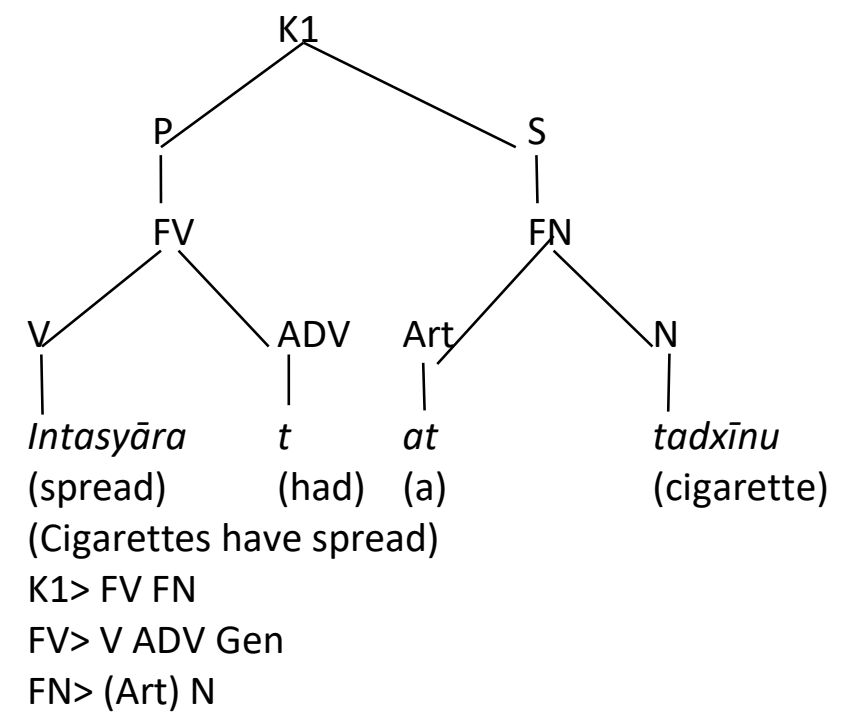

Sentence 1 (K1) in data (1) is an intransitive active sentence because the predicate function in the sentence does not require an object. The predication function is filled by the prerequisite verb phrase and the subject function is filled by the noun phrase at-tadxinu. Sentence pattern 1 shows that the predicate consisting of V, Adv, and Gen is located at the beginning, while the subject is at the end so that the pattern of the sentence is PS. The following are the analysis of transitive active sentences in Arabic with an SPO pattern.

(2) laqad a'thā al ilāhun kilā al ixwan aini mālan

(Have) (give) (have) (Allah) (second) (brother) (two) (treasure)

"Allah has given wealth to these brothers."

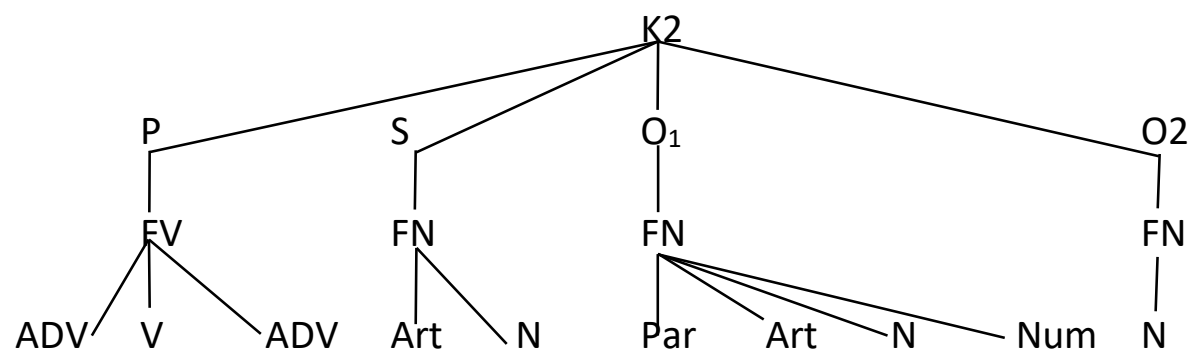




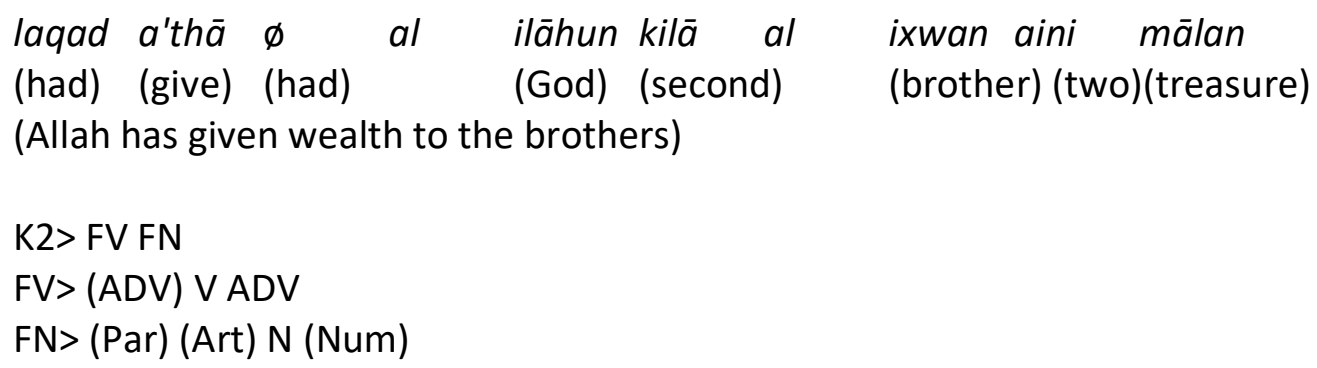

The second sentence (K2) in data (2) is a transitive active sentence that requires two objects. In K2, the P function is filled by FV which consists of particles in the form of the word laqad which means that when followed by the past verb, and the verb a'tha which shows the adverb of time $\varnothing$ (zero) which means showing the past verb. The $S$ function is filled by FN, while the $\mathrm{O} 1$ and $\mathrm{O} 2$ functions are also filled by FN. The rule of sentence structure in K2 is PS01-02.

(3) Wa al tadxīnu qatlu li al nafsi

(And) (a) (cigarette) (kill) (to) (a) (soul)

"Cigarettes kill the soul."

The third sentence (K3) in data (3) shows a more complex tree diagram because the sentence is a transitive active sentence whose predicate function requires an object. The $S$ function in $\mathrm{K} 3$ is filled by $\mathrm{FN}$ which consists of Konj + Art $+\mathrm{N}$. The predicate function in $\mathrm{K} 3$ is filled with infinitive nouns, namely nouns derived from verbs (Schulz, 2012: 121). The adverb can be seen in the following tree diagram.

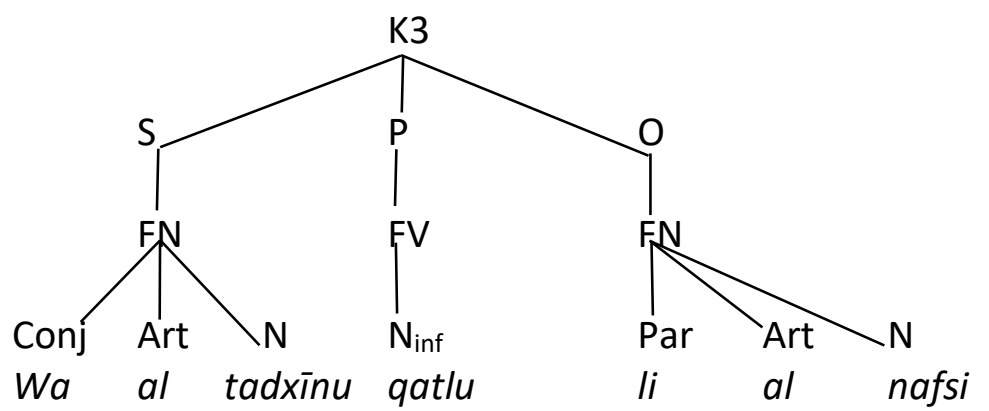

(and) (a) (cigarette) (kill) (for) (a) (soul)

(Cigarettes kill the soul)

K2> FN FV FN

$\mathrm{FN}>$ (Conj) (Par) (Art) N

FV $>$ Ninf

Adverbs of time can only be attached to the original verb and cannot be attached to infinitive verbs. Meanwhile, the $\mathrm{O}$ function is filled by the FN category, which consists of Par + Art $+\mathrm{N}$.

From the findings above, it can be concluded that the adverbial time inherent in verbs are only found in verbs that come from the original verb and not the derivational verb. Besides, Arabic simple sentence patterns that attached by adverb of time are also found in the book Al-Arabiyah Baina Yadaik Volume 4, consisting of PS, SP, SPO, and PSO. 


\section{The distribution of adverb of time in Arabic simple sentence}

Chomsky (2002) states that distribution is all positions occupied by language elements. The following are athen analysis table of the distribution of adverbs of time in Arabic simple sentences.

(4) Māta al-abu.

(Died) (father).

'Father (has) died.'

Table 1. adverb of time in the Predicate

\begin{tabular}{|l|l|l|}
\hline \multirow{3}{*}{$4)$} & Mata & $a$ - $a b u$ \\
\cline { 2 - 3 } & Died (v perfect, pron 3, male singular) & Father (definite noun) \\
\cline { 2 - 3 } & Father (has) died & \\
\hline
\end{tabular}

The sentence in the data (4) is an intransitive sentence. In data (4) there is the word māta which is a perfect verb (expressing past adverb of time) which is implied to contain the third person pronoun, singular male. The verb has a function as a predicate. Meanwhile, the word al-abu is a definite noun that functions as a subject. The adverb of time is inherent in the word mata as the predicate.

(5) Jā'a hu Jibrīlu bi awwali sūratin minal Qur'āni fí Ramadhāna 'āmi al-arba'îna limaulidihi. (has come) (it) (Angel Gabriel) (with) (beginning) (letter) (from) (Al-Qur'an) (at) (month of Ramadan) (on) (year) (40th) (since birth).

'Jibril came to him with the first letter that was revealed in the Qur'an in the month of Ramadan at the age of $40 . '$

Table 2. Adverb of time located behind the object

\begin{tabular}{|c|c|c|c|c|c|c|c|c|c|c|}
\hline \multirow[t]{4}{*}{ (5) } & $J \bar{a} ' a$ & \multicolumn{2}{|l|}{ hu } & \multicolumn{2}{|c|}{ Jibrīlu } & bi & Awwali & sūratin & minal & Qur'āni \\
\hline & \multirow{2}{*}{$\begin{array}{l}\text { already come } \\
\text { ( } \mathrm{v} \text { perfect } \\
\text { pronoun } 3 \\
\text { male singular, } \\
\text { functions as } \mathrm{P} \text { ) }\end{array}$} & \multirow{2}{*}{\multicolumn{2}{|c|}{$\begin{array}{l}\text { his } \\
\text { (pronoun } \\
3, \quad \text { male } \\
\text { singular, } \\
\text { functions } \\
\text { as O) }\end{array}$}} & \multirow{2}{*}{\multicolumn{2}{|c|}{$\begin{array}{l}\text { Jibril } \\
\text { (noun } \\
\text { as S) }\end{array}$}} & \multicolumn{2}{|c|}{\begin{tabular}{|l|l|} 
With & Early \\
\end{tabular}} & letter & from & $\begin{array}{l}\text { Al- } \\
\text { Qur'an }\end{array}$ \\
\hline & & & & & & \multicolumn{5}{|c|}{ ADV1 } \\
\hline & \multicolumn{10}{|c|}{$\begin{array}{l}\text { Jibril came to him with the first letter that was revealed in the Qur'an in the month } \\
\text { of Ramadan at the age of } 40 \text {. }\end{array}$} \\
\hline$F \overline{F I}$ & \multicolumn{2}{|c|}{ Ramadhāna } & \multicolumn{2}{|c|}{ minal } & 'ām & \multicolumn{2}{|c|}{ al-arba'ìna } & \multicolumn{3}{|c|}{ limaulidihi } \\
\hline On & \multicolumn{2}{|c|}{ Ramadhan month } & \multicolumn{2}{|c|}{ On } & yeal & \multicolumn{2}{|c|}{ 40th } & \multicolumn{3}{|c|}{ since his birth } \\
\hline
\end{tabular}

The sentence in the data (5) shows that the adverb of time can be located after the object. The word jā'a is a perfect verb that denotes the past tense and denotes the 3rd singular male pronoun. Hu functions as an object denoting the 3rd pronoun and referring to the Prophet Muhammad. Meanwhile, Jibril is the subject. The first statement states the meaning of means, in answer to the question "How did the angel Gabriel come?" While the second statement states the meaning of time in order to answer the question "When did the angel Gabriel come to Muhammad?".

(6) Faqad kāna yadhkhaku wa yamzakhu bi Al-qauli Ash-shādiq.

(Has) (at that time) (laughs) (and) (kidding) (with) (speech) (honest).

'At that time the Prophet laughed and joked with honest words.' 
Table 3. Adverb of time that is located in front of the predicate

\begin{tabular}{|c|c|c|c|c|c|c|c|c|}
\hline \multirow[t]{3}{*}{ (6) } & Faqad & Kāna & yadhkhaku & $W a$ & Yamzakhu & $b i$ & Al-qauli & $\begin{array}{l}\text { Ash- } \\
\text { shādiq }\end{array}$ \\
\hline & $\begin{array}{l}\text { Has } \\
\text { been }\end{array}$ & $\begin{array}{l}\text { at that } \\
\text { time }\end{array}$ & \multirow{2}{*}{$\begin{array}{l}\text { Laugh } \\
\text { ( } \mathrm{v} \\
\text { imperfect, } \\
\text { pron 3, sing } \\
\text { male, serves } \\
\text { as P which } \\
\text { implies the } \\
\text { function S) }\end{array}$} & \multirow[t]{2}{*}{$\begin{array}{l}\text { and } \\
\text { (conj) }\end{array}$} & \multirow{2}{*}{$\begin{array}{l}\text { Kidding } \\
\text { (v } \\
\text { imperfectpron } \\
3 \text {, sing male, } \\
\text { serves as } P \\
\text { which implies } \\
\text { the S) }\end{array}$} & with & words & honest \\
\hline & \multicolumn{2}{|c|}{ ADV1 } & & & & \multicolumn{3}{|c|}{ ADV2 } \\
\hline
\end{tabular}

The sentence in the data (6) shows that the adverb of time in a single Arabic sentence can come before yadhkhaku as the predicate. The word qad is a particle which emphasizes that the event occurred in the past. Meanwhile, kāna is a verb that also has a means of meaning.

(7) Lam yakun al-masjidu fi al-mādhī makāna shalātin fakhashbu.

(not) (to be) (mosque) (in) (past) (place) (prayer) (only)

"In ancient times, mosques did not only function as places of prayer."

Table 4. Adverb of time located behind the subject

\begin{tabular}{|c|c|c|c|c|c|c|c|c|}
\hline \multirow[t]{4}{*}{ (7) } & Lam & Yakun & $\begin{array}{l}\text { al- } \\
\text { masjidu }\end{array}$ & fi & $a l-m \bar{a} d h \bar{~}$ & makana & shalātin & $\begin{array}{l}\text { fakhash- } \\
\text { bu }\end{array}$ \\
\hline & \multirow[t]{2}{*}{$\begin{array}{l}\text { Not } \\
\text { (neg) }\end{array}$} & \multirow{2}{*}{$\begin{array}{l}\text { Becomes } \\
\text { (imperfect } \\
\text { verb which } \\
\text { shows the } \\
\text { present time, } \\
\text { functions as P) }\end{array}$} & \multirow[t]{2}{*}{$\begin{array}{l}\text { Mosque } \\
\text { (definite } \\
\text { noun as } \\
\text { S) }\end{array}$} & $\begin{array}{l}\text { in } \\
\text { (part) }\end{array}$ & $\begin{array}{l}\text { past } \\
\text { (definite noun } \\
\text { denoting the } \\
\text { past) }\end{array}$ & the place & Salat & only \\
\hline & & & & & ADV & \multicolumn{3}{|c|}{0} \\
\hline & In an & times & le di & ol & cction as a & tor & & \\
\hline
\end{tabular}

The sentence on the data (7) shows that the adverb of time (fi-almadhi) can lie after the subject ( $a$ l-masjidu). The predicate function is filled by the negation verb, namely lam yakun, which indicates an imperfect verb. But there is a time lag that shows what happened in the sentence occurred in the past.

From the findings above, it can be concluded that the adverbial elements inherent in verbs are only found in verbs that come from the original verb and not the derivational verb. Besides, by using tree diagram the researcher reveals the Arabic simple sentence patterns that attached by adverb of time in the book Al-Arabiyah Baina Yadaik Volume 4. there are four patterns consisting of predicate subject (PS), subject predicate (SP), subject predicate object (SPO), and predicate subject object (PSO).

Furthermore, it was found that the distribution of adverb of time in Arabic simple sentence that is inherent in Predicate, behind Object, in front of Predicate, and behind Subject. The result of this research can be considered as a complementary of the previous research results conducted by Nur (2018) who investigates tense and aspect in Arabic in the 
frame of a semantic approach and also research by Al-Shammiry (2016) describing type of adverb in Saudi northern dialect of Arabic.

\section{Conclusion}

Based on the analysis above, it can be concluded that the adverbial elements inherent in a simple sentence are only found in verbs that come from the original verb and not derived from the verb. In addition, Arabic sentence patterns were also found in the book Al-Arabiyah Baina Yadaik Volume 4a consisting of PS, SP, SPO, and PSO. Furthermore, based on the analysis the researchers found that the distributions of adverb of time are as follows: (1) the distribution of adverb of time that is inherent in the predicate, (2) the distribution of adverb of time located behind the object, (3) the distribution of adverb of time located in front of the predicate, and (4) distribution of the adverb of time which lies behind the subject.

The result of this research is expected to be useful as a reference for understanding the distribution of adverbial time in Arabic. Moreover, this research is expected to inspire other researchers to investigate the topic from another theoretical approach or examine the adverbs of time in other languages.

\section{References}

Al-Fauzan, et al. (2014). Al-Arabiyah Baina Yadaik Volume 4a. Jakarta: PT. Future Media Gate. Al-Shammiry, K. M. J. (2016). "Adverbs in Saudi Nothern Dialect of Arabic (SNRDA)". International Journal of English Linguistics, Vol. 6 (1). http://www.ccsenet.org/ journal/index.php/ijel/article/view/56998.

Chomsky, Noam. (2002). Syntactic Structures. Berlin and New York: Mouton de Gruyter.

Dahda, A. 1981. Mu'jam Qawa'id al-Lutghah al-'Arabiyah. Beirut: Maktabah Lubnan.

Febriani, Vovi, et.al. (2015). Proses Morfologi atau Konstruksi Kata dalam Bahasa Arab. Jurnal Diskursus Islam, Vol. 03 (3), Desember 2015. 401-414. http://journal.uinalauddin.ac.id/index.php/diskursus_islam/article/view/7440.

Kridalaksana, Harimurti. (2002). Struktur, Kategori, dan Fungsi dalam Teori Sintaksis. Jakarta: Universitas Katolik Indonesia Atma Jaya

Liusti, Siti Ainim. (2016). Analisis Kalimat Berdasarkan Pola Kalimat Dasar dan Kalkulus Predikat. Adabiyyat, Vol. XV (2), Desember 2016. 157-175. http://ejournal.uinsuka.ac.id/adab/Adabiyyat/article/view/1064/761.

Nur, Tajudin. (2018). Pernyataan Kala dan Aspek dalam Bahasa Arab: Analisis Semantik Verba.

Arabi: Journal of Arabic Studies, Vol. 3 (1), 2018.2 36-51. http://journal.imla.or.id/index.php/arabi/article/view/65.

Ramlan, M. 2005. Sintaksis. Yogyakarta: Karyono.

Schulz, Eckehard. 2012. Bahasa Arab Baku dan Modern. Yokyakarta: LKIS Printing Cemerlang.

Sudaryanto. (2015). Metode dan Aneka Teknik Analisis Bahasa. Yogyakarta: Duta Wacana University.

Suharto, T., dan Fauzi, A. (2017). Analisis Kesalahan Sintaksis Dalam Buku Teks Bahasa Arab Untuk Perguruan Tinggi Keagamaan Islam. Arabiyât : Jurnal Pendidikan Bahasa Arab dan Kebahasaaraban, 4, (1). https://core.ac.uk/download/pdf/296425321.pdf.

Susandhika, et. al. (2016). Fungsi, Kategori, dan Peran Sintaksis Dalam Talk Show One "Indonesia Lawyers Club" di TV One. LINGUISTIKA, Vol. 23. No. 44. https://www.researchgate.net/publication/346037213_ANALISIS_KALIMAT_BERDAS ARKAN_POLA_KALIMAT_DASAR_DAN_KALKULUS_PREDIKAT_1. 